\title{
Development and Validation of a new Multidimensional Questionnaire called Muslim Medical Student Questionnaire (MMSQ) among Malaysian Undergraduates.
}

\author{
Ramli Musa ${ }^{1}$, M. Fauzi Abdul Rani ${ }^{2}$, Aminudin Che A. ${ }^{3}$, Samsul Draman ${ }^{4}$ \\ ${ }^{1}$ Department of Psychiatry, Kulliyah of Medicine, International Islamic University Malaysia Kuantan \\ ${ }^{2}$ Faculty of Medicine, Universiti Teknologi MARA, 40450 Shah Alam, Selangor \\ ${ }^{3}$ Department of Orthopedic, Kulliyyah of Medicine, International Islamic University Malaysia Kuantan \\ ${ }^{4}$ Department of Family Medicine, Kulliyyah of Medicine, International Islamic University Malaysia Kuantan
}

\begin{abstract}
Introduction: A handful of medical schools have implemented the Islamic input in medical program into their medical curricula. However we are facing a setback as there is no validated standard assessment tool to measure the effectiveness of this academic input for undergraduate medical programme. Therefore the objective of this study is to design a scale that is able to gauge the impact of the Islamic input among medical undergraduates. Materials and Methods: The construction of a new scale is based on the 5 stages of standard questionnaire design. To validate the newly designed scale, it was administered to all the medical students who granted their consent. Results: A total of 520 students from all academic years of a medical school were enrolled in the validation stage. Bartlet's KMO value is 0.9 . From 46 items, $67 \%$ had good factor loading $(>0.4)$. Cronbach's alpha values of $0.78,0.85$ and 0.13 were obtained for Attitude, Practice and Knowledge domains respectively. We identified the 3 domains by using exploratory factor analysis. Conclusion: The scale has good psychometric values for both reliability and validity.
\end{abstract}

KEYWORDS: Muslim doctor, Muslim medical student, religiosity, efficacy, professionalism.

Conflict of interest; Nil

\section{INTRODUCTION}

The world of higher education is converging on the need for evidence based educational program. In the effort to produce quality doctors, the world of academia is pressured to prove that their medical programmes are capable of producing well-rounded doctors who are equipped with knowledge and skills, and possess good attitude. In the blueprint of Malaysian education that is the Malaysian Qualification Framework (MQF), it clearly outlines the 3 important components. They are cognitive (knowledge), psychomotor (skills) and affective (attitude and ethics). ${ }^{1}$

The International Islamic University Malaysia (IIUM) has pioneered the model of Islamic Input into its Medical Program (IIMP). To date there are a number of medical schools around the globe that have introduced a similar module to the IIMP. Unfortunately many aspects of the module are not

Corresponding Author:

Dr. Ramli Musa

Professor, Department of Psychiatry,

Kulliyah of Medicine,

International Islamic University Malaysia,

Jalan Hospital, 25150 Kuantan, Pahang, Malaysia

Telephone: +6017-9690111

Email: ramlidr@yahoo.com; drramli@iium.edu.my evidence based and the reason for this is because there is very little research conducted in the area. Lately however, we are beginning to see efforts in data collection and analysis of the effectiveness of IIMP. ${ }^{2}$

In order to evaluate the effectiveness of IIMP in a medical program, there is a need to develop and validate a simple and practical assessment tool or a scale in a form of a questionnaire that encompasses the 3 domains of knowledge, practice and attitude. The new scale will act as a single method of assessment in addition to the other assessment approaches such examination and student portfolio. This study has strong ramifications, as the availability of a validated assessment tool would enable researchers to gather and study the evidence of the effectiveness of IIMP in tertiary education. To the best of our knowledge, currently there are no tools that test the efficacy, professionalism and religiosity of Muslim doctors. There are several religiosity tools that test the religiosity of Muslim youths and Muslims in general, but there is none that specifically measures the knowledge, attitude and professionalism of Muslim doctors.

The final objective of IIMP is to ensure that the 
IMJM Volume 17 Special Issue No 2

makeup of the graduates would be well-rounded Muslim doctors. Therefore it is significant to investigate whether they have acquired the specifications in all the domains that constitute the makeup of a good and competent Muslim doctor. Hence, the objective of this study is to invent a scale and to evaluate its validity and reliability to measure the impact of IIMP. The usage of this scale has been expended to other Islamic based medical schools in Malaysia and Indonesia. There are also ongoing studies to compare the level of competency between various medical universities in Malaysia and Indonesia. We hope with this scientific evidence, the world of Islamic academia could nurture the best curriculum in pursuing the objective of producing balanced Muslim medical doctors.

\section{MATERIALS AND METHODS}

The study was approved by the internal review board of International Islamic University ethics committee. The drafting the scale was based on the Malaysian National Education Blueprint as our main reference.

\section{Questionnaire construction}

The development of the questionnaire was divided into 5 stages. Generally the stages were simplified as; stage1; identify the themes or domains of the scale, stage 2; identify items for each domain, stage 3 ; pretesting on the pre final version, Stage 4; pilot study with 50 subjects and stage 5 ; validation of the questionnaires on minimum of 500 Muslim medical students. As stated in the Malaysia's Higher Education Blueprint 2015-2025, we decided that the 3 main domains were Knowledge, Attitude and Practice.

Stage 1 was to gather an overview on domains and subscales of characteristics of good Muslim doctors. A total of 20 individuals identified as stakeholders of Muslim doctors comprising of spiritual leaders, academicians, patients, medical students, doctors, health practitioners, teachers and Muslim NGO representatives. The participants gave their opinions on the good characteristics of Muslim doctors through feedback forms and a series of faceto-face meetings. The feedbacks were themed on four domains namely knowledge, attitude, practice and others (miscellaneous). Based on the feedbacks and discussion, the characteristics of a well-rounded doctor were noted to revolve around the 3 stated domains above.

At stage 1 , we were able to identify a few broad areas enumerated by the respondents. The proposed domains were; Knowledge (religiosity, medical Fiqh and Islamic worldview), Attitude (morality, sincerity, ethics and outward manifestation) and finally Practice (communication skills, professionalism and self-realization). Stage 2 was designed to construct the items in each identified domain. The suggested items were formulated and finalized by a group of experts consisting of academicians and Islamic scholars.

Stage 3 was to pretest the pre final product. The aim of this stage was to look for any ambiguous terms and sentence structures of the pre final questionnaire before researchers embarked on the pilot study. Pre-test would ensure that the items were well understood, jargon-free and unambiguous. The pretest was conducted on a small group of volunteers comprising of university students. Sentence by sentence review was conducted on 5 students with different backgrounds to find out whether the sentences and words used were easily understood. If there was any ambiguous or difficult word, an alternative word was suggested.

Finally we identified that there were 16 items for Knowledge, 9 items for Attitude and 21 items for Practice, a total of 46 items for this new scale. These items will be a mixture of characteristics of an ideal Muslim doctor and its negative aspects of to avoid the scoring bias or error by future users.

The scoring of each domain was designed differently to cater for the purpose of the assessment tool. For example the Knowledge domain, the scoring was decided as "true", "unsure" and "false". Whereas for Attitude, the scoring was designed based on the level of conviction (strongly agree, agree, disagree and strongly disagree). For Practice domain, the scoring was based on the frequency of the item being practiced (regularly, sometimes, seldom and never).

Stage 4 was a pilot study that was conducted on 50 Muslim doctors at a public hospital. In this stage, we conducted preliminary psychometric analyses and we obtained Cronbach's alpha of 0.78 and interitem correlations between 0.8 and 0.9 . Following a favorable pilot study result we then proceeded to stage 5 without any alteration done to pre-final version of the scale.

Stage 5 was the validation of the scale with bigger sample size. A total of 520 subjects comprising of IIUM Muslim medical students were involved and the aim of this stage was to validate the final version of Muslim Medical Student Questionnaire (MMSQ).

There was no standard rule to determine the number of subjects needed for the validation stage. However the calculation of adequate sample size was based on the number of items. Since the total items were 46, the estimation of adequate subjects was at least 460 subjects (10 respondents for each item). The inclusion criterion was anyone who was English literate. We proposed name of this questionnaire to be Muslim Medical Student Questionnaire (MMSQ).

\section{RESULTS}


Table I: Socio-demographic data of the respondents

\begin{tabular}{lccc}
\hline Variable & N & $\begin{array}{c}\text { Percentage } \\
\text { (\%) }\end{array}$ & Total \\
\hline Gender & 219 & 42.1 & 520 \\
Male & 301 & 57.9 & \\
Female & 131 & 25.2 & 520 \\
Academic year & 117 & 22.5 & \\
Year 1 & 92 & 17.7 & \\
Year 2 & 82 & 15.8 & \\
Year 3 & 98 & 18.8 & \\
Year 4 & & & \\
Year 5 & 335 & 65.6 & \\
& & 34.4 & \\
Have you ever re- & & & \\
ceived a formal & & & \\
Islamic curriculum & 176 & & \\
at previous schools? & & & \\
Yes & & & \\
No & & & \\
If the answer is yes, & & & \\
which school is the & 148 & & \\
respondent received & 123 & 36.7 & \\
the Islamic curricu- & 64 & 19.1 & \\
lum? & & \\
Primary school & & \\
Secondary school & & \\
Both & & & \\
\hline
\end{tabular}

We included all registered IIUM Muslim medical students in this study. A total of 520 medical students from Kulliyyah (Faculty) of Medicine IIUM participated in the study. This figure represented $90.1 \%$ of total registered students (577) in the medical course. The distribution of all the students according to their academic years is detailed in table 1. From a total of 511 students who responded to the survey question, 335 students had received formal Islamic teaching in their previous academic education. Of this figure, majority $(44 \%)$ received the Islamic education in primary school, $37 \%$ received it in their secondary school and 19\% received in both primary and secondary schools.

\section{Reliability of the scale}

Based on internal consistency, Cronbach's alpha values of $0.13,0.78$ and 0.85 were obtained for Knowledge, Attitude and Practice domains respectively. We could observe that Knowledge had the poorest Cronbach's alpha value $(0.13)$ of all 3 values.

\section{Validity based on Exploratory Factor Analysis}

Table II: Factor loading of each item based on Exploratory Factor Analysis

\begin{tabular}{|c|c|c|c|c|}
\hline Domains & $\begin{array}{l}\text { Item } \\
\text { Symbol }\end{array}$ & Items & $\begin{array}{l}\text { Componen } \\
\text { factor load } \\
1\end{array}$ & \\
\hline \multirow[t]{15}{*}{ Knowledge } & \multirow{2}{*}{$\begin{array}{l}\mathrm{K} 1 \\
\mathrm{~K} 2 \\
\mathrm{~K} 3\end{array}$} & \multirow{2}{*}{$\begin{array}{l}\text { There are } 4 \text { pillars in Maqasad Syariah } \\
\text { "Aqal" is one of the pillars in Maqasad Syariah } \\
\text { A Muslim female patient should only be seen by a female gy- } \\
\text { naecologist. }\end{array}$} & \multicolumn{2}{|r|}{0.18} \\
\hline & & & \multicolumn{2}{|l|}{0.30} \\
\hline & K4 & $\begin{array}{l}\text { Islam encourages a 3-month pregnant mother to fast during } \\
\text { Ramadhan provided there is no medical problem }\end{array}$ & & 0.22 \\
\hline & K5 & $\begin{array}{l}\text { In any circumstances, Muslim patients can take medications, } \\
\text { which contain pig by- products. }\end{array}$ & 0.18 & 0.20 \\
\hline & K6 & Taking oral medication while fasting will not break the fast. & \multicolumn{2}{|l|}{0.17} \\
\hline & K7 & $\begin{array}{l}\text { A Muslim doctor is allowed to perform vasectomy or tubal liga- } \\
\text { tion when the patients request it. }\end{array}$ & \multicolumn{2}{|l|}{0.22} \\
\hline & $\mathrm{K} 8$ & Using eye drops will nullify fasting. & \multicolumn{2}{|l|}{0.18} \\
\hline & K9 & $\begin{array}{l}\text { Muslim physicians should not care for homosexual patients } \\
\text { with AIDS as this is endorsing homosexuality. }\end{array}$ & \multicolumn{2}{|l|}{0.44} \\
\hline & K10 & Sunnat Dhuha prayer is performed in middle of the night. & \multicolumn{2}{|l|}{0.35} \\
\hline & K11 & $\begin{array}{l}\text { The concept of Ruksah is applied to simplify the performance } \\
\text { of prayers during difficult situations. }\end{array}$ & \multicolumn{2}{|l|}{0.43} \\
\hline & K12 & Performance of Tayammum involves 4 body parts. & \multicolumn{2}{|l|}{0.37} \\
\hline & K13 & Fasting is encouraged on Tuesdays and Fridays & \multicolumn{2}{|l|}{0.24} \\
\hline & K14 & Surah Al-Fatihah is also known as a healing surah. & \multirow{2}{*}{\multicolumn{2}{|c|}{$\begin{array}{l}0.26 \\
0.24\end{array}$}} \\
\hline & K15 & A false Hadith is also known as Hadith Dhoif (weak) & & \\
\hline & K16 & $\begin{array}{l}\text { The use of Qada' in performing prayers is applicable when a } \\
\text { surgical operation involves long hours. }\end{array}$ & \multicolumn{2}{|l|}{0.41} \\
\hline \multirow[t]{2}{*}{ Attitude } & A1 & $\begin{array}{l}\text { I do not see the need to inculcate spiritual values in my medi- } \\
\text { cal practice }\end{array}$ & & 0.47 \\
\hline & A2 & $\begin{array}{l}\text { Constant request for an update from either patient or family } \\
\text { members should not be encouraged. }\end{array}$ & & 0.39 \\
\hline
\end{tabular}




\begin{tabular}{|c|c|c|c|c|c|}
\hline & A3 & \multicolumn{3}{|l|}{$\begin{array}{l}\text { The concept of Maqasid Syariah should be applied to problematic } \\
\text { cases encountered in clinical medicine. }\end{array}$} & \multirow[t]{2}{*}{0.35} \\
\hline & A4 & I consciously adopt Islamic values when dealing with my patients & 0.58 & & \\
\hline & A5 & $\begin{array}{l}\text { When revealing the diagnosis of HIV to a patient, I believe it } \\
\text { should be done in private. }\end{array}$ & & & 0.55 \\
\hline & A6 & Medical confidentiality is important in my practice & & & 0.55 \\
\hline & A7 & My work as a doctor is an Ibadah & & & 0.48 \\
\hline & A8 & I feel that the effort that I do is not well rewarded. & & & 0.44 \\
\hline & A9 & I work mainly for the salary. & & 0.30 & 0.15 \\
\hline \multirow[t]{18}{*}{ Practice } & P1 & I relate to the Quran and Hadith in my reasoning. & 0.47 & & \\
\hline & P2 & I make effort to read Quran regularly & 0.40 & & \\
\hline & P3 & I greet almost every patient that I meet with Salam. & 0.48 & & \\
\hline & P4 & I communicate effectively with my colleagues and patients. & 0.37 & & \\
\hline & $\begin{array}{l}\text { P5 } \\
\text { P6 }\end{array}$ & $\begin{array}{l}\text { I always perform prayer while on duty. } \\
\text { I perform congregational prayers } 5 \text { times per day. }\end{array}$ & $\begin{array}{l}0.44 \\
0.60\end{array}$ & & \\
\hline & P7 & $\begin{array}{l}\text { When patients inquire about Rukshah in sickness, I am able to } \\
\text { deal with it. }\end{array}$ & 0.53 & & \\
\hline & P8 & $\begin{array}{l}\text { I am comfortable talking to intensely demanding patients' } \\
\text { relatives. }\end{array}$ & 0.56 & & \\
\hline & P9 & $\begin{array}{l}\text { I allocate time to explain about the disease to my patients or the } \\
\text { relatives. }\end{array}$ & 0.46 & & \\
\hline & P10 & $\begin{array}{l}\text { I am not late for clinical appointments such as clinics, ward } \\
\text { rounds and meetings. }\end{array}$ & 0.56 & & \\
\hline & P11 & I remind my colleagues or subordinates about professionalism. & 0.57 & & \\
\hline & P12 & $\begin{array}{l}\text { I am happy with the way I deal with people around me and they } \\
\text { respond to me positively too. }\end{array}$ & 0.66 & & \\
\hline & P13 & I practise the Prophet's sunnah in my life & 0.52 & & \\
\hline & P14 & $\begin{array}{l}\text { I recite Bimillah (By the name of Allah) before every task in my } \\
\text { life. }\end{array}$ & 0.79 & & \\
\hline & $\begin{array}{l}\text { P15 } \\
\text { P16 }\end{array}$ & $\begin{array}{l}\text { I practise Islamic counselling when dealing with patients } \\
\text { I perform sunnat Dhuha, Tahajud and Witr. }\end{array}$ & 0.79 & & \\
\hline & P17 & I follow the Akhlak of Prophet Muhammad SAW & 0.60 & & \\
\hline & $\begin{array}{l}\text { P18 } \\
\text { P19 }\end{array}$ & $\begin{array}{l}\text { I can recognize Bid'ah and Khurafat in the community. } \\
\text { I can deal with a Janazah according to Syariah. }\end{array}$ & $\begin{array}{l}0.40 \\
0.45\end{array}$ & & \\
\hline & P20 & $\begin{array}{l}\text { I constantly remind my patients about the need to perform } \\
\text { prayers. }\end{array}$ & 0.64 & & \\
\hline & P21 & I memorize common short Surahs in Al Quran & 0.19 & 0.42 & \\
\hline
\end{tabular}

Based on Principal Component Analysis by using Varimax rotation, 3 components were extracted. Factor 1 corresponded to Practice domain, factor 2 for Knowledge and factor 3 for Attitude. Generally items in Practice have better factor loadings (0.37-0.79) as compared items in Attitude and Knowledge domains. If we were to make a comparison between Knowledge and Attitude, again Knowledge items scored the poorest factor loadings $(0.18-0.44)$. Kaiser-Meyer-Olkin value obtained in our analysis was 0.9 which is statistically significant $(\mathrm{p}=0.001)$. Similarly Hotelling's T-squared value measured was 238.5 with $\mathrm{p}=0.001$. Therefore, these measurements indicate the adequacy of sample size in this study as perquisite for component factor analysis.

\section{DISCUSSION}

Spirituality has been increasingly recognized as an important element in human health. When discussing spirituality, we could not run away from the component of religiosity. Both spirituality and religiosity are very much interrelated and they are commonly being used interchangeably. Some researchers argue the validity of using a scale to measure the religiosity based on the fact that religiosity is something intangible but on the other hand there are many established and validated scales to measure depression, which is also considered as intangible.

Based on studies in the past on the aspect of religiosity and health, we know that there is a strong positive correlation between religiosity or religious belief and the level of general health. ${ }^{3}$ Religiosity is also associated with a few biological parameters such as blood pressure and somatic symptoms. ${ }^{4}$ In a local study done by Momtaz et al, there is a significant relationship between religiosity and chronic health problems. ${ }^{5}$ 
In terms of religiosity scales, there are not many studies that are done in this area. The efforts in the past were mainly focusing on establishment of spirituality scales. There have been attempts to design such Islamic religiosity scales lately. ${ }^{6}$ However to the best of our knowledge, there has never been a study to design specifically a religiosity scale that could gauge the Islamic practice and competency among medical practice. Many Western-developed religious inventories are based on the Christian concept of God. ${ }^{7,8}$ A past study by Kandari et al, the measurement of the level of religiosity was done by using single item scale as another dimensional approach. The study reported that even by only using a single item measurement, it demonstrated good temporal stability, concurrent validity and factorial validation. ${ }^{9}$

Based on the Malaysia's Higher Education Blueprint 2015-2025, one of the main focuses is to have better assessment of a newly designed curriculum on the students. The blueprint has clearly stated that the curriculum should highlight the holistic education so that it could mold the students on the aspects of ethics and morality (Akhlak), knowledge and skills $(I l m u)$. There is a need to ensure that the high monetary investment on higher educational programmes yields the outcomes that the government and society want. ${ }^{1}$

We had designed our scale using a multidimensional approach. Based on a few recent empirical evidence, multidimensional approach of measuring religiosity is more appropriate and comprehensive. ${ }^{10,11}$ This approach is also supported by the fact that Muslim religiosity has many facets, domains and dimensions. ${ }^{12}$ Based on our discussion with Islamic scholars in stages 1 and 2 of this study, we concluded that multidimensional approach was the best way to devise the scale. Among the important domains identified in the discussion were effective communication (skill), Islamic Medical jurisprudence and ethics, honesty (Akhlak), and adequate Islamic knowledge. ${ }^{13}$

Based on our results, we notice that Attitude and Practice domains generally having better Cronbach alpha and factor loadings. This means that items in Practice and Attitude are more stable in term of their consistency. Why it is so? We believe that attitude and practice are more consistent in their behaviours and their abilities to measure the said purposes.

Having poor Cronbach's alpha in the domain of Knowledge is something interesting to discuss and it is not a surprise to us. Researchers and statisticians have cited that there are situations where the computation of Cronbach alpha is simply not appropriate. A good example is assessment of knowledge on a subject matter in an educational program. The low Cronbach's alpha is expected at the beginning of the educational program indicating that people had lack of knowledge on the subject hence they would answer randomly. Improper interpretation of Cronbach's alpha could lead to a situation where a scale is criticized for not generating trustworthy results. To avoid this situation an understanding of the associated concepts of internal consistency, homogeneity or unidimensionality can help to improve the use of alpha. ${ }^{14,15}$

Item 21 was expected to be in Practice domain but had high factor loading in Knowledge domain. When we analysed the item, we found out that the nature of the question was more suitable at assessing knowledge rather than practice. This item was about the ability in memorizing Quranic surah (verses) rather than the practice of reciting Quran. We also observed the factor loadings for Practice was quite high (> 0.4 except for items P4 and P5). Both poor items in Practice were about performing prayer; performing prayer while on duty (P4) and performing congregational prayers (P5). Here we were unable to make any reference or comparison with any study in the past, as there has never been any study done to design religious scale for medical practitioners. There are however many studies that show good concurrent validity and factorial validity for other religiosity self- rating scales. ${ }^{7,16,17,18}$

Our study affirms the idea that multidimensionality is a better approach in measuring the Islamic religiosity or spirituality. Our scale is relatively short as compared to other Islamic religiosity scale such as Multidimensional Measure of Islamic Spirituality (MMS). MMS consists of 75 items with 8 domains. When comparing between our scale and MMS, there are similarities in several domains such as faith conviction (Iman), moral practice, selfdiscipline and responsibilities. ${ }^{18}$

We notice a few similarities with regards to the concept of domains in our newly designed scale and a religiosity scale invented by Parsian et al. We notice practice and belief or attitude are present in both scales. ${ }^{19}$ In order to have more robust evidence, we recommend that it is necessary to expand the validation on different subject groups and detailed statistical analysis such as Structural Equation Modeling (SEM).

\section{CONCLUSION}

This new scale called MMSQ has good psychometric properties. The results of this study may act as an initial validation finding. We plan for further robust studies with involvement of more students from other medical schools to enhance the psychometric properties of this scale. The questionnaire is protected by copyright.

\section{REFERENCES}

1. Malaysia's Higher Education Blueprint 2015-2025 - the implementation challenge. Prof Christine Ennew, Provost, University of Nottingham Malaysia Campus Pro Vice Chancellor and 
Professor of Marketing, University of Nottingham Malaysia Campus. The Observatory News analysis GA5 23Jul15

2. Jamilah J, Ahmad Najib A, Dzulkhairi MR, Ariff HO , Nasri Ismail NM Integration of Islamic Input in Medical Curriculum - Universiti Sains Islam Malaysia (USIM) Experience. International Medical Journal Malaysia. 2014; 13(2): 73-77.

3. Oman D, Reed D Religion and mortality among the community-d welling elderly. Am J Public Health. 1998; 88(10): 1469- 1475

4. Francis L, Katz Y, Yablon Y, Robbins M (2004). Religiosity, Personality, and Happiness: A Study among Israeli Male Undergraduates. Journal of Happiness Studies. 2004; 5(4): 315- 333.

5. Momtaz YA, Hamid TA, Yahaya N The Role of Religiosity on Relationship between Chronic Health Problems and Psychological Well-Being among Malay Muslim older persons. Research Journal of Medical Sciences. 2009; 3(2): 188-193.

6. Abdel-Khalek AM, Lester D. Religiosity, health, and psychopathology in two cultures: Kuwait and USA. Mental Health, Religion \& Culture. 2007; 10 (5): 537- 550.

7. Krauss SE, Hamzah A, Idris F. Adaptation of a Muslim Religiosity Scale for Use with Four Different Faith Communities in Malaysia. Review of Religious Research. 2007; 49(2): 147-164.

8. Abdel-Khalek AM. Religiosity, health, and wellbeing among Kuwaiti personnel. Psychol Rep. 2008; 102(1): 181-18 4

9. Al-Kandari YY. Religiosity, Social Support and Health among the elderly in Kuwait. Journal of Muslim Mental Health. 2011; 1(1): 81-97.

10.Fetzer Institute, National Institute on Aging Workshop Group. Multidimensional measurement of religiousness and spirituality for use in health research. Kalamazoo: Fetzer Institute; 1999.

11.Glock CY. Über die Dimensionen der Religiosität. In J. Matthes (Ed.), Kirche und Gesellschaft: Einführung in die Religionssoziologie. Reinbek bei Hamburg: Rowohlt. 1969; 150-168.

12.David L Streiner Geoffrey R Norman, John Cairney. Health Measurement Scales $\left(5^{\text {th }}\right.$ edition). 2014.

13.Ghorbani N, Watson PJ, Khan ZH. Theory and practice, theoretical, empirical, and potential ideological dimensions of using western conceptualizations to measure Muslim religious commitments. Journal of Muslim Mental Health. 2007; 2(2): 113-131.

14.Tavakol M., Dennick R. Making sense of Cronbach's alpha. International Journal of Medical Education. 2011; 2:53-55.

15.Schmitt N. Uses and abuses of coefficient alpha. Psychological Assessment. 1996; 8:350-353.

16.Abdel-Khalek AM. Assessment of intrinsic religiosity with a single-i tem measure in a sample of Arab Muslims. Journal of Muslim Mental Health. 2007a; 2: 211- 215.

17.Abdel- Khalek A.M. Religiosity, happiness, health, and psychopathology in a probability sample of Muslim adolescents. Mental Health, Religion \& Culture. 2007b; 10(6): 571-583.
18.Dasti R, Sitwat A. Development of a Multidimensional Measure of Islamic Spirituality (MMS). Journal of Muslim Mental Health. 2014; 8 (2): 47-67.

19.Parsian N, Dunning T. Developing and Validating a Questionnaire to Measure Spirituality: A Psychometric Process. Global Journal of Health Science. 2009; 1(1) 2-8. 
Appendix 1

The Muslim Medical Student Questionnaire (MMSQ)

1 There are 4 pillars in Maqasad Syariah

True

Unsure

False

2 "Aqal" is one of the pillars in Maqasad Syariah

3 A Muslim female patient should only be seen by a female gynaecologist.

4 Islam encourages a 3-month pregnant mother to fast during Ramadhan provided there is no medical problem

5 In any circumstances, Muslim patients can take medications that contain pig by- products.

6 Taking oral medication while fasting will not break the fast.

7 A Muslim doctor is allowed to perform vasectomy or tubal ligation when the patients request it.

8 Using eye drops will nullify fasting.

9 Muslim physicians should not care for homosexual patients with AIDS as this is endorsing homosexuality.

10 Sunnat Dhuha prayer is performed in middle of the night.

11 The concept of Ruksah is applied to simplify the performance of prayers during difficult situations.

12 Performance of Tayammum involves 4 body parts.

13 Fasting is encouraged on Tuesdays and Fridays

14 Surah Al-Fatihah is also known as a healing surah.

15 A false Hadith is also known as Hadith Dhoif (weak)

16 The use of Qada' in performing prayers is applicable when a surgical operation involves long hours.

\section{ATTITUDE}

\begin{tabular}{|c|c|c|c|c|c|c|}
\hline & & $\begin{array}{l}\text { Strongly } \\
\text { agree }\end{array}$ & Agree & $\begin{array}{l}\text { Don't } \\
\text { know }\end{array}$ & Disagree & $\begin{array}{l}\text { Strongly } \\
\text { disagree }\end{array}$ \\
\hline 1 & $\begin{array}{l}\text { I do not see the need to inculcate } \\
\text { spiritual values in my medical practice }\end{array}$ & & & & & \\
\hline 2 & $\begin{array}{l}\text { Constant request for an update from } \\
\text { either patient or family members }\end{array}$ & & & & & \\
\hline 3 & $\begin{array}{l}\text { The concept of Maqasid Syariah should } \\
\text { be applied to problematic cases }\end{array}$ & & & & & \\
\hline 4 & $\begin{array}{l}\text { I consciously adopt Islamic values when } \\
\text { dealing with my patients }\end{array}$ & & & & & \\
\hline 5 & $\begin{array}{l}\text { When revealing the diagnosis of HIV to a } \\
\text { patient, I believe it should be done in }\end{array}$ & & & & & \\
\hline 6 & $\begin{array}{l}\text { Medical confidentiality is important in } \\
\text { my practice }\end{array}$ & & & & & \\
\hline 7 & My work & & & & & \\
\hline 8 & $\begin{array}{l}\text { I feel that the effort that I do is not } \\
\text { well rewarded. }\end{array}$ & & & & & \\
\hline
\end{tabular}


1 I relate to the Quran and Hadith in my reasoning.

2 I make effort to read Quran regularly

3 I greet almost every patient that I meet with Salam.

$4 \quad$ I communicate effectively with my colleagues and patients.

5 I always perform prayer while on duty.

6 I perform congregational prayers 5 times per day.

7 When patients inquire about Rukshah in sickness, I am able to deal with it.

8 I am comfortable talking to intensely demanding patients' relatives.

9 I allocate time to explain about the disease to my patients or the relatives.

10 I am not late for clinical appointments such as clinics, ward rounds and meetings.

11 I remind my colleagues or subordinates about professionalism.

12 I am happy with the way I deal with people around me and they respond to me positively too.

13 I practise the Prophet's sunnah in my life

14 I recite Bimillah (By the name of Allah) before every task in my life.

15 I practise Islamic counselling when dealing with patients

16 I perform sunnat Dhuha, Tahajud and Witr.

17 I follow the Akhlak of Prophet Muhammad SAW

18 I can recognize Bid'ah and Khurafat in the community.

19 I can deal with a Janazah according to Syariah.

20 I constantly remind my patients about the need to perform prayers.

21 I memorize common short Surahs in Al Quran $\quad<10$ surah $\quad 10$ to15 16 to $25 \quad>25$ (please circle) 
Appendix 2

Scoring Guide of the Muslim Medical Student Questionnaire (MMSQ)

\section{KNOWLEDGE}

\begin{tabular}{|c|c|c|}
\hline & & Reasons/answer/argument \\
\hline 1 & There are 4 pillars in Maqasad Syariah & $\begin{array}{l}\text { Wrong, there are } 5 \text { pillars; life, } \\
\text { religion, aq'al (mind), property and } \\
\text { dignity. }\end{array}$ \\
\hline 2 & "Aqal" is one of the pillars in Maqasad Syariah & Correct \\
\hline 3 & $\begin{array}{l}\text { A Muslim female patient should only be seen by a } \\
\text { female gynaecologist. }\end{array}$ & $\begin{array}{l}\text { Wrong. If available, same sex health } \\
\text { care providers are encouraged but, if } \\
\text { not available and in life saving } \\
\text { situations, "necessity overrides the } \\
\text { prohibition" - a rule of Islamic Sariah. }\end{array}$ \\
\hline 4 & $\begin{array}{l}\text { Islam encourages a } 3 \text {-month pregnant mother to fast } \\
\text { during Ramadhan provided there is no medical } \\
\text { problem }\end{array}$ & $\begin{array}{l}\text { Wrong. It is preferable that you utilize } \\
\text { God's granted exemption and do not } \\
\text { fast. Your baby is dependent on you } \\
\text { for his or her nutrition and hydration. } \\
\text { Why do you want him or her to fast } \\
\text { with you? }\end{array}$ \\
\hline 5 & $\begin{array}{l}\text { In any circumstances, Muslim patients can take } \\
\text { medications, which contain pig by- products. }\end{array}$ & $\begin{array}{l}\text { Wrong Muslims should not take these } \\
\text { medicines unless they are lifesaving } \\
\text { drugs and no substitute is available. }\end{array}$ \\
\hline 6 & $\begin{array}{l}\text { Taking oral medication while fasting will not break } \\
\text { the fast. }\end{array}$ & $\begin{array}{l}\text { Wrong. Oral medication will break the } \\
\text { fast. }\end{array}$ \\
\hline 7 & $\begin{array}{l}\text { A Muslim doctor is allowed to perform vasectomy or } \\
\text { tubal ligation when the patients request it. }\end{array}$ & $\begin{array}{l}\text { Wrong. Such procedures are prohibited } \\
\text { in Islam except to save the life of the } \\
\text { mother. Thus, like Catholic Physicians, } \\
\text { Muslim Physicians also may not } \\
\text { perform them. }\end{array}$ \\
\hline 8 & Using eye drops will nullify fasting. & $\begin{array}{l}\text { Wrong; dropping eye drops into eyes } \\
\text { will not nullify the fast. }\end{array}$ \\
\hline 9 & $\begin{array}{l}\text { Muslim physicians should not care for homosexual } \\
\text { patients with AIDS as this is endorsing homosexuality. }\end{array}$ & $\begin{array}{l}\text { Wrong. We do not discriminate other } \\
\text { patients because of their lifestyle } \\
\text { (smokers, alcoholics, over eaters etc.) } \\
\text { nor should we do so for AIDS patients. }\end{array}$ \\
\hline 10 & $\begin{array}{l}\text { Sunnat Dhuha prayer is performed in middle of the } \\
\text { night. }\end{array}$ & $\begin{array}{l}\text { Wrong (it should be performed in the } \\
\text { morning) }\end{array}$ \\
\hline 11 & $\begin{array}{l}\text { The concept of Ruksah is applied to simplify the } \\
\text { performance of prayers during difficult situations. }\end{array}$ & Correct \\
\hline 12 & Performance of Tayammum involves 4 body parts. & Wrong, 2 parts only (face and hands) \\
\hline 13 & Fasting is encouraged on Tuesdays and Fridays & Wrong; Answer; Monday \& Thursday \\
\hline 14 & Surah Al-Fatihah is also known as a healing surah. & Correct \\
\hline 15 & A false Hadith is also known as Hadith Dhoif (weak) & $\begin{array}{l}\text { Wrong, Hadith Dhoif if weak Hadith } \\
\text { not wrong hadith }\end{array}$ \\
\hline 16 & $\begin{array}{l}\text { The use of Qada' in performing prayers is applicable } \\
\text { when a surgical operation involves long hours. }\end{array}$ & $\begin{array}{l}\text { Wrong, the solution for long hour } \\
\text { operation is to perform Jamak } \\
\text { (accumulative) prayer. }\end{array}$ \\
\hline
\end{tabular}




\begin{tabular}{|c|c|c|}
\hline 1 & $\begin{array}{l}\text { I do not see the need to inculcate spiritual values in my medical } \\
\text { practice }\end{array}$ & $\begin{array}{l}\text { Spirituality } \\
\text { Comprehensive }\end{array}$ \\
\hline 2 & $\begin{array}{l}\text { Constant request for an update from either patient or family } \\
\text { members should not be encouraged. }\end{array}$ & Communication \\
\hline 3 & $\begin{array}{l}\text { The concept of Maqasid Syariah should be applied to problematic } \\
\text { cases encountered in clinical medicine. }\end{array}$ & $\begin{array}{l}\text { Islamic Medical } \\
\text { Jurisprudence }\end{array}$ \\
\hline 4 & I consciously adopt Islamic values when dealing with my patients & Islamic Ethics \\
\hline 5 & $\begin{array}{l}\text { When revealing the diagnosis of HIV to a patient, I believe it } \\
\text { should be done in private. }\end{array}$ & Confidentiality \\
\hline 6 & Medical confidentiality is important in my practice & Confidentiality \\
\hline 7 & My work as a doctor is an Ibadah & Conviction \\
\hline 8 & I feel that the good work that I do is not well rewarded. & Honesty \\
\hline 9 & I work mainly for the salary. & Sincerity \\
\hline
\end{tabular}

Domain/tested area

\begin{tabular}{|c|c|c|}
\hline 1 & T relate to the Quran and Hadith in my reasoning. & Ibadah (practice) \\
\hline 2 & I make effort to read Quran regularly & Ibadah (practice) \\
\hline 3 & I greet almost every patient that I meet with Salam. & Interpersonal Affective \\
\hline 4 & I communicate effectively with my colleagues and patients. & Communication \\
\hline 5 & I always perform prayer while on duty. & Ibadah (practice) \\
\hline 6 & I perform congregational prayers 5 times per day. & Ibadah (practice)) \\
\hline 7 & $\begin{array}{l}\text { When patients inquire about Rukshah in sickness, I am able to deal } \\
\text { with it. }\end{array}$ & Religiosity (Rukhshah) \\
\hline 8 & $\begin{array}{l}\text { I am comfortable talking to intensely demanding patients' } \\
\text { relatives. }\end{array}$ & $\begin{array}{l}\text { Communication } \\
\text { Skills; }\end{array}$ \\
\hline 9 & $\begin{array}{l}\text { I allocate time to explain about the disease to my patients or the } \\
\text { relatives. }\end{array}$ & Interpersonal skills \\
\hline 10 & $\begin{array}{l}\text { I am not late for clinical appointments such as clinics, ward rounds } \\
\text { and meetings. }\end{array}$ & Punctuality \\
\hline 11 & I remind my colleagues or subordinates about professionalism. & Professionalism \\
\hline 12 & $\begin{array}{l}\text { I am happy with the way I deal with people around me and they } \\
\text { respond to me positively too. }\end{array}$ & $\begin{array}{l}\text { Akhlak } \\
\text { /Personality }\end{array}$ \\
\hline 13 & I practise the Prophet's sunnah in my life & Ibadah \\
\hline 14 & $\begin{array}{l}\text { I recite Bimillah (By the name of Allah) almost every task in my } \\
\text { life. }\end{array}$ & Ibadah \\
\hline 15 & I practise Islamic counselling when dealing with patients & Ibadah and skill \\
\hline 16 & I perform sunnat Dhuha, Tahajud and Witr. & Ibadah \\
\hline 17 & I follow the Akhlak of Prophet Muhammad SAW & Akhlak \\
\hline 18 & I can recognize Bid'ah and Khurafat in the community. & Aqidah \\
\hline 19 & I can deal with a Janazah according to Syariah. & Ibadah \\
\hline 20 & I constantly remind my patients about the need to perform prayers. & Dakwah \\
\hline 21 & I memorize common short Surahs in Al Quran & $\begin{array}{l}\text { Ibadah and } \\
\text { knowledge }\end{array}$ \\
\hline
\end{tabular}

